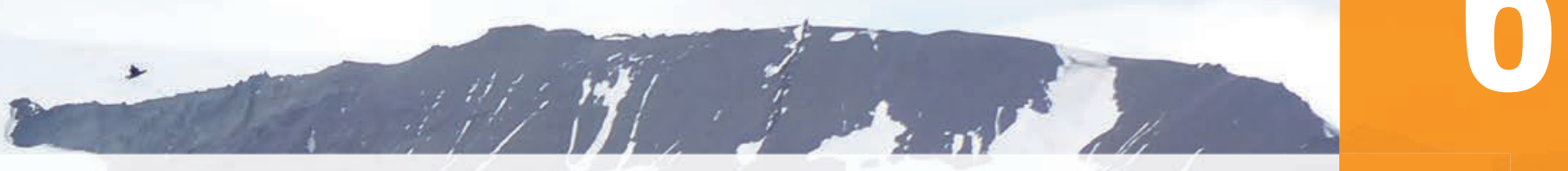

\title{
HISTOLOGY AND HISTOCHEMICAL CHARACTERISATION OF THE STOMACH STRUCTURE OF THE ANTARCTIC FISH Notothenia rossii (RICHARDSON, 1844) UNDER CONDITIONS OF THERMAL STRESS
}

\author{
Priscila Krebsbach Kandalski*, Axel Helmut Rulf Cofré1, Cintia Machado, \\ Maria Rosa Dmegeon Pedreiro de Souza', Flávia Baduy Vaz da Silva', Tânia Zaleski, \\ Luciana Badeluk Cettina ${ }^{1}$, Mariana Forgati ${ }^{1}$, Claudio Adriano Piechnik ${ }^{1}$, \\ Edson Rodrigues ${ }^{2}$ \& Lucélia Donatti ${ }^{1}$

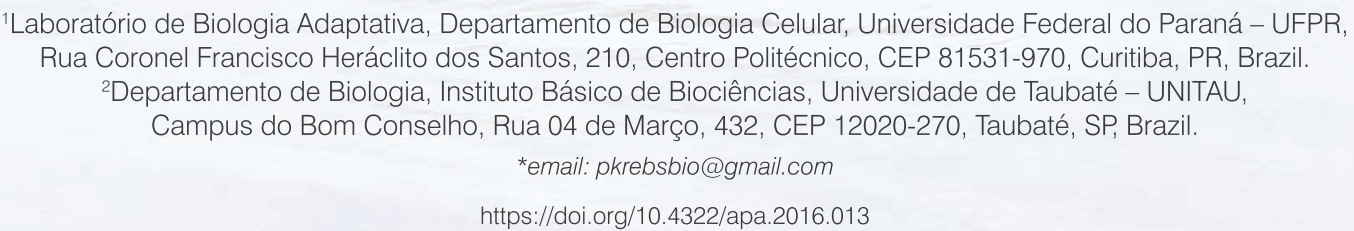

Abstract: Ecological impacts of climate change on marine environments have been significant in the Antarctic Peninsula. Ecological responses may affect fish fauna from the species level to community level. Our goal was to analyze histological and histochemical aspects of three stomach portions (cardiac, fundic and pyloric) of Notothenia rossii, an antarctic fish, under thermal stress using light microscopy. Fish were collected in Admiralty Bay and taken to the Brazilian Antarctic station "Comandante Ferraz". Fish ( $n=5 /$ bioassay) were acclimated in seawater tanks $\left(0^{\circ} \mathrm{C} / 35 \%\right.$ ) and exposed to temperatures of $0^{\circ} \mathrm{C}$ (control), $4^{\circ} \mathrm{C}$ and $8^{\circ} \mathrm{C}$ during 1, 4, 15 and 30 days. Samples were processed and stained with haematoxylin/eosin, Periodic Schiff acid, Alcian-Blue pH 2.5 and 1.5. Heating caused an increase in the muscle layer of fundic and pyloric regions in samples kept for 1 day at $8^{\circ} \mathrm{C}$ and 4 days at $4^{\circ} \mathrm{C}$, compared with the control group. Expression of neutral glycosaminoglycans was not affected by increasing temperature. Thermal stress caused a reduction in expression of carboxylated and sulfated-glycosaminoglycans in samples kept at $8^{\circ} \mathrm{C} d u$ ring 1 , 4 and 30 days. However, the stomach does not show histological and histochemical standard alterations under different thermal stress conditions and, therefore, we cannot be conclusive about the lack of full functionality.

Keywords: Nototheniidae, Stomach, Histochemistry, Thermal Stress.

\section{Introduction}

Temperature directly or indirectly affects living organisms, determining metabolic rate and the development of digestive chemical reactions and metabolic processes (Kapoor et al., 1975; Ba-Omar \& Victor, 2000; Silva \& Araújo-Lima, 2003; Kawaguchi, 2007; Handeland, 2008) and increases susceptibility to histopathology in some chronic cases. Nevertheless, there are few studies focused on the morpho-histology (Freiberger, 1996) and functional aspects of the digestive system of Antarctic fishes subjected to thermal stress (Hernandez-Blazquez et al., 2006).
Therefore, this study aims to carry out the histological and histochemical characterisation of the stomach structure of Notothenia rossii under different conditions of thermal stress.

\section{Materials and Methods}

Samples of Notothenia rossii were captured with hook and line in Admiralty Bay (Lat.: $61^{\circ} \mathrm{S}$ and $63^{\circ} 30^{\prime} \mathrm{S} /$ Long.: $53^{\circ} 55^{\prime} \mathrm{W}$ and $62^{\circ} 50^{\prime} \mathrm{W}$ ), in King George Island, South Shetlands Archipelago, Antarctica. The experiment was

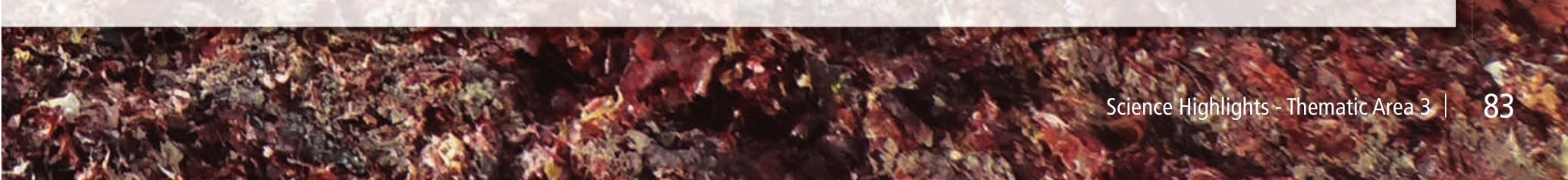




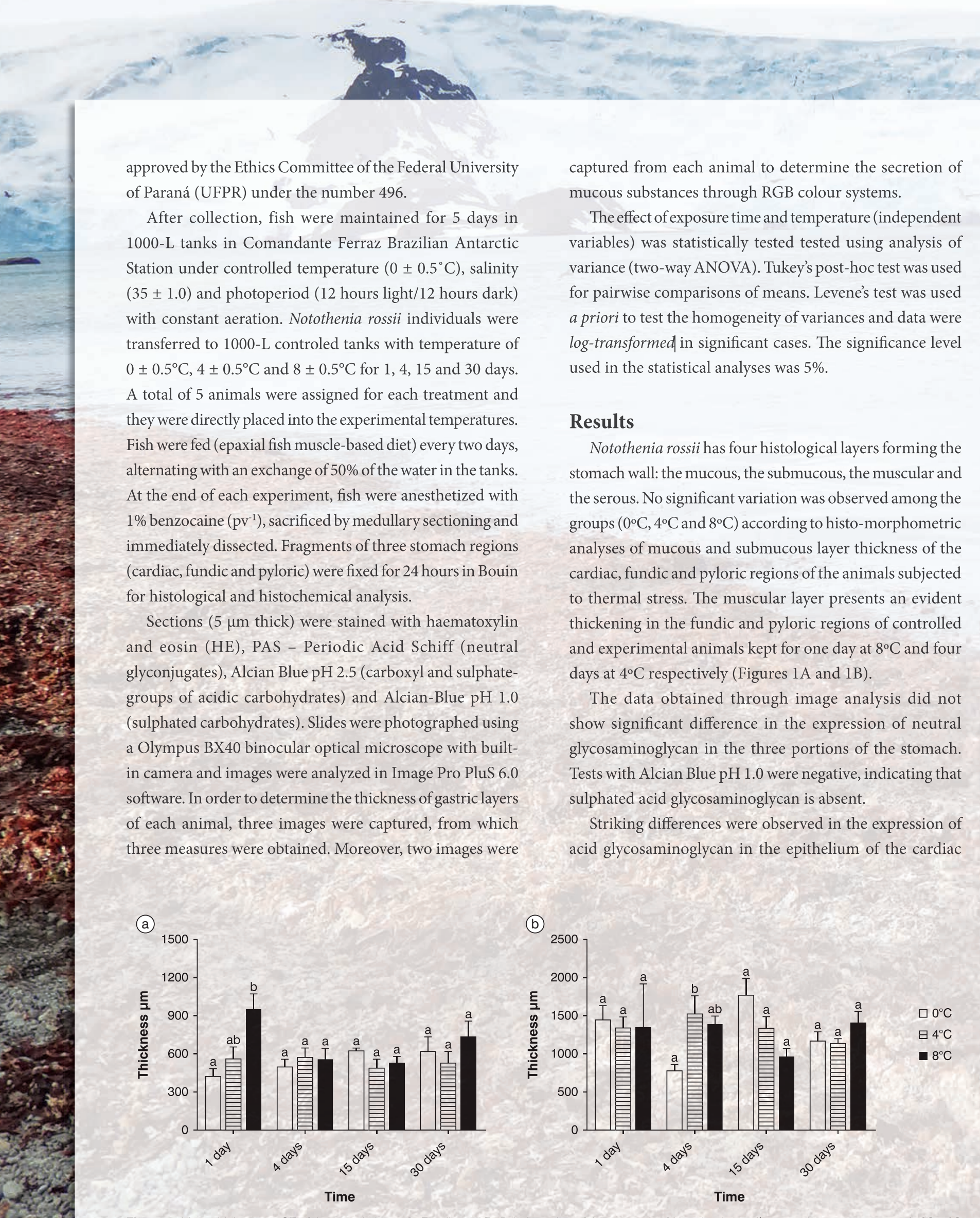

Figure 1. Mean thickness $\pm \mathrm{SE}$ of the muscle layer. A. Fundic and B. Pyloric region of the stomach of Notothenia rossii exposed to temperatures of $0^{\circ} \mathrm{C}, 4^{\circ} \mathrm{C}$ and $8^{\circ} \mathrm{C}$ for $1,4,15$ and 30 days. Different letters indicate statistical differences in the thickness of the muscle layer due to increase of temperature. (Tukey test, $p<0.05)$. 


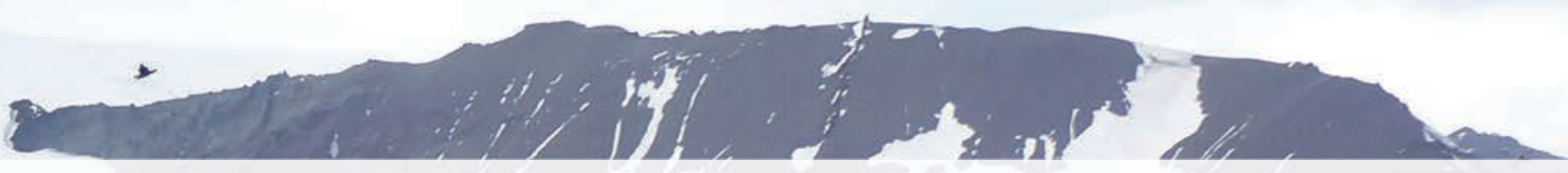

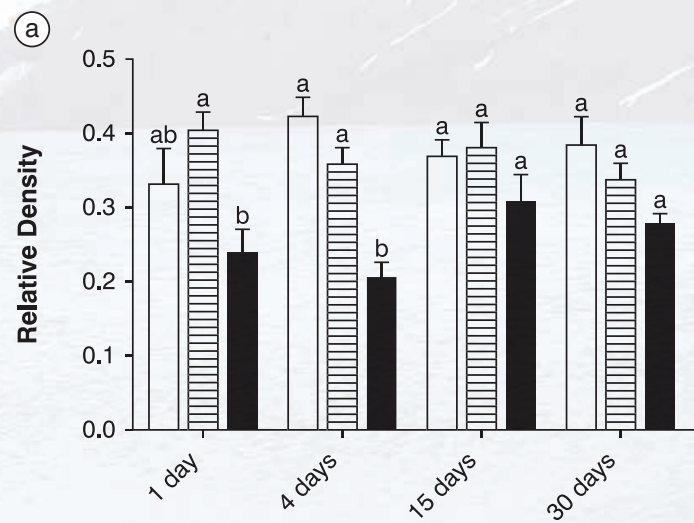

(b)
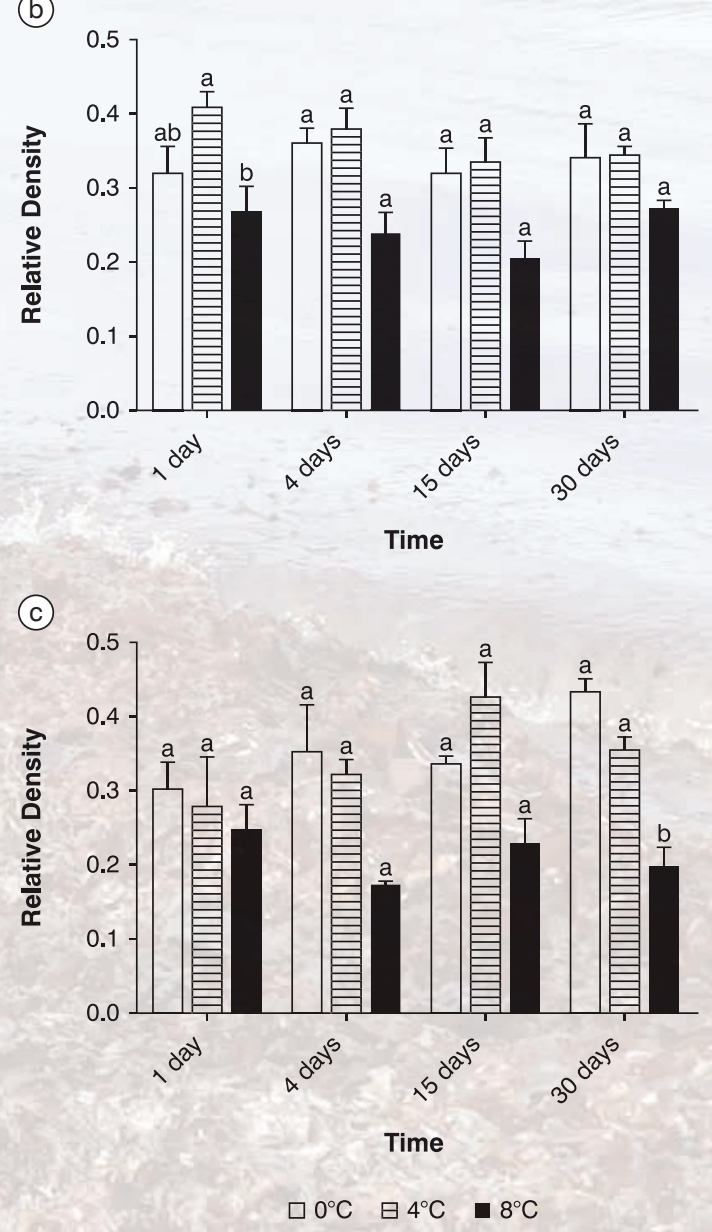

Figure 2. Relative density of acidic glycosaminoglycans (Alcian blue $\mathrm{pH}$ 2.5). A. Cardiac; B. Fundic and C. Pyloric region of the stomach of Notothenia rossii exposed to temperatures of $0^{\circ} \mathrm{C}, 4^{\circ} \mathrm{C}$ and $8^{\circ} \mathrm{C}$ for $1,4,15$ and 30 days. Notice the significant difference represented by different letters in A. groups of 1 and 4 days, B. 1 day and C. 30 days. (Tukey test, $p<0.05$ ). and fundic regions of animals kept for one day at $4^{\circ} \mathrm{C}$ and $8^{\circ} \mathrm{C}$ (Figure 2A and 2B). Animals kept for four days at $8^{\circ} \mathrm{C}$ showed a meaningful decrease in the expression of acid glycosaminoglycan in the cardiac region when compared to the control and $4^{\circ} \mathrm{C}$ groups. A slight presence of acid glycosaminoglycan was noticed in the epithelium of the pyloric region of animals kept at $8^{\circ} \mathrm{C}$ for 30 days (Figure $2 \mathrm{C}$ ).

\section{Discussion and Conclusions}

Temperature is a relevant environmental factor for fishes in the sense that influences nourishing rates, action of digestive enzymes, gastric and intestinal motility, secretion rate of digestive juice and intestine absorption rate (Kapoor et al., 1975; Silva \& Araújo-Lima, 2003), and may lead to changes in metabolic responses. Studies on stomach histology of fish under the effects of thermal stress are missing, but studies with mammals indicate that alterations in mucous layers may, in the long term, compromise gastric evacuation, which, in turn, tends to lead to increased acidic concentration inside the stomach and, consequently, gastric ulcers (Meyer, 1999)

In this paper, it was possible to observe that the thickness of the muscular layer of the fundic region increased in the fishes exposed for one day to $8^{\circ} \mathrm{C}$ heating, as well as in the pyloric region of animals kept for four days at $4^{\circ} \mathrm{C}$. The muscular layer of the pyloric region is thicker than that of the cardiac and fundic regions, which suggests that there is a facilitation of ejection of food through peristaltic activity towards the intestine (Rodrigues and Menin, 2008). Bastos-Ramos et al. (2000) demonstrated that the increase in temperature leads to a proportional muscle relaxation on the intestine smooth muscle of the Notothenia neglecta (coriiceps) and of the Chaenocephalus aceratus.

According to Domeneghini et al. (2002), most teleosts have gastric glands in cardiac and fundic regions. In the current study, gastric glands were detected in the three regions of the stomach, just as it happens in Trycomycterus brasiliensis (Oliveira-Ribeiro \& Fanta, 2000). Gastric epithelial coating shows positive PAS apical mucous substances that serves particularly forfunctions such as lubrication, digestion, absorption of carbohydrates and fatty acids, control of infectious diseases, colonisation of harmful and opportunistic microorganisms and regulation of the gastric $\mathrm{pH}$ (Cao \& Wang, 2009; Díaz 


\section{Acknowledgements}

This work is part of the National Institute of Science and Technology for Antarctic Environmental Research (INCT-APA) that receives scientific and financial support from the National Council for Research and Development (CNPq process: $n^{\circ}$ 574018/2008-5) and from the Carlos Chagas Research Support Foundation of the State of Rio de Janeiro (FAPERJ n ${ }^{\circ}$ E-16/170.023/2008). The authors also acknowledge the support of the Brazilian Ministry of Science, Technology and Innovation (MCTI), Ministry of Environment (MMA) and Inter-Ministry Commission for Sea Resources (CIRM).

\section{References}

Ba-Omar, T. A., \& Victor, R. (2000). Ultrastructural changes in the epithelium of the stomach of Aphanius dispar (Cyprinodontidae), due to stress from starvation. Science and Technology, 5, 1-9.

Bastos-Ramos, W. P., Hoshino, K., \& Bacila, M. (2000). Temperature-dependent tonic contraction of smooth muscle in Antarctic fishes Notothenia neglecta and Chaenocepha/us aceratus: role of calcium ions and responses to acetycholine. Polar Bioscience, 13, 74-86.

Cao, X. J., \& Wang, W. M. (2009). Histology and mucin histochemistry of the digestive tract of Yellow Catfish, Pelteobagrus fulvidraco. Anatomia, Histologia, Embryologia, 38, 254-261.

Díaz, A. O., García, A. M., Figueroa, D. E., \& Goldemberg, A. L. (2008). The mucosa of the digestive tract in Micropogonias furnieri: A Light and Electron microscope approach. Anatomia, Histologia, Embryologia, 37, 251-256.

Domeneghini, C., Radaelli, G., Bosi, G., Arrighi, S., Di Giancamillo, A., Pazzaglia, M., \& Mascarello, F. (2002). Morphological and histochemical diferences in the structure of the alimentary canal in feeding and runt (feed deprived) white sturgeons (Acipenser transmontanus). Journal of Applied Ichthyology, 18, 341-346.

Freiberger, S. Estudo histológico e ultraestrutral do estômago e aspectos do comportamento alimentar do peixe antártico Notothenia neglecta Nybelin, 1951 submetido a períodos de jejum. (Dissertação de mestrado em ciências morfológicas. Concentração biologia celular). Universidade Federal do Paraná, 1996.

Handeland, S. O., Imsland, A. K., \& Stefansson, S. O. (2008). The effect of temperature and fish size on growth, feed intake, food conversion efficiency and stomach evacuation rate of Atlantic salmon post-smolts. Aquaculture, 283, 36-42.

Hernandez-Blazquez, F. J., Guerra, R. R., Kfoury, J. R. Jr, Bombonato, P. P., Cogliati, B., \& Silva, J. R. M. C. (2006). Fat absorptive processes in the intestine of the Antarctic fish Notothenia coriiceps (Richardson, 1844). Polar Biology, 29, 831-836.

Kapoor, B. G., Smit, H., \& Verighina, I. A. (1975). The alimentary canal and digestión in teleosts. Advances in Marine Biology, $13,109-239$.

Kawaguchi, Y., Miyasakas, H., Genkai-Katos, M., Taniguchi, Y., \& Nakano, S. (2007). Seasonal change in the gastric evacuation rate of rainbow trout feeding on natural prey. Journal of Fish Biology, 71, 1873-1878.

Meyer, T. N., \& Silva, A. L. (1999). Resposta celular ao estresse. Revista da Associação Médica Brasileira, 45(2)

Oliveira-Ribeiro, C. A., \& Fanta, E. (2000). Microscopic morphology and histochemistry of the digestive system of a tropical freshwater fish Trichomycterus brasiliensis (Lükten) (Siluroidei, Trichomycteridae). Revista Brasileira de Zoologia, 17(4), 953-971. 


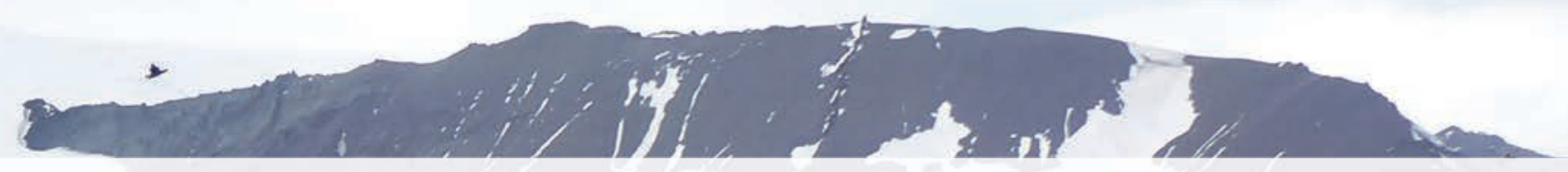

Rodrigues, S. S., \& Menin, E. (2008). Anatomia do tubo digestivo de Salminus brasiliensis (Cuvier, 1817) (Pisces, Characidae, Salmininae). Biotemas, $21(2), 65-75$.

Silva, E. C. S., \& Araújo-Lima, C. A. R. M. (2003). Influência do tipo de alimento e da temperatura na evacuação gástrica da piranha caju (Pygocentrus nattereri) em condições experimentais. Acta Amazonica, 33(1), 145-155.

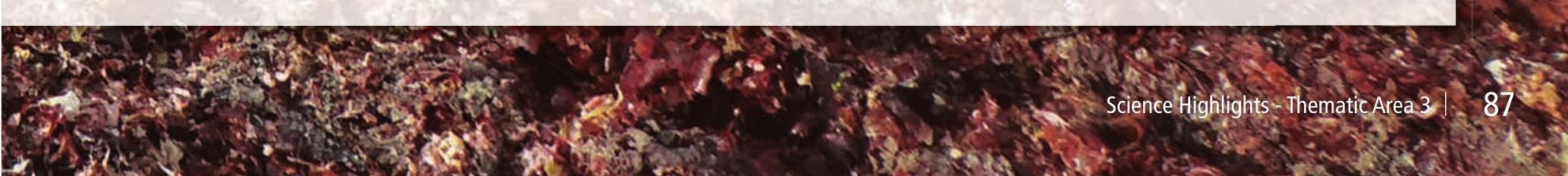

